\title{
The contemporary look at the problem of recognizing and diagnosing postmenopausal osteoporosis and eliminating the risk of a fall
}

\author{
Mariola Janiszewska, Teresa Bernadetta Kulik, Małgorzata Anna Dziedzic, Dorota Żołnierczuk-Kieliszek \\ Katedra Zdrowia Publicznego, Uniwersytet Medyczny w Lublinie
}

\begin{abstract}
Osteoporosis constitutes a relevant health, social and economic problem of the contemporary world. As a chronic disease, often nicknamed the "silent thief", it is an object of the clinical research and a reason for many ambiguities. The most noticeable and basic symptom of osteoporosis is a low-energy fracture, which brings pain, physical disability, and a noticeable decrease in one's quality of life. Osteoporosis affects the entire population; however, women in the postmenopausal period and the elderly are mostly exposed to its progress. The risk of falling ill concerning women simply grows with the age and doubles with every decade after the age of 65. It is estimated that osteoporosis affects 200 million women worldwide, and about 20-25\% of them will sustain an injury in the form of a bone fracture. In Poland, the problem of osteoporosis concerns 2.4 million women. The article attempts to show current views on examining and diagnosing postmenopausal osteoporosis and prevention of the fall risk. The BMD (bone mineral density) is considered the basis of osteoporosis diagnosis in postmenopausal women as well as an absolute 10-year risk of fractures and experienced osteoporotic fractures. All people at an increased fall risk should be provided with the multifactorial programme of fall prevention.
\end{abstract}

Key words: osteoporosis, menopause, bone mineral density, fracture risk, fall prevention.

\section{Introduction}

Osteoporosis is considered one of the most common diseases in adult population. Statistics show that this illness constitutes the most widely spread osteopathy, affecting about 75 million people in Europe, the USA and Japan, including every third postmenopausal woman and the majority of elderly people over 70 [1].

The word "osteoporosis" comes from the Greek "osteon" - meaning the bone and from the Latin "porus" - meaning the hole or loss [2]. According to the definition of National Osteoporosis Foundation experts and National Institutes of Health (NOF/NIH), osteoporosis is an illness of the skeleton, characterized by an increased risk of bone fractures and reduced mechanical bone resistance $[2,3]$. Bone mineral density and the quality of bone tissue influence mechanical resistance [3-5]. The essence of osteoporosis is low-energy fractures of the upper extremity of the thigh bone, vertebras, ribs, humerus, radial and tibial bones caused by minor injuries and being a result of reduced mechanical strength. Lorenc et al. [6] define the osteoporotic fracture as "a fracture disproportionate to forces it is caused by, which occurs after a fall from one's own height, excluding other causes, e.g. the pathologic fracture". The most common fractures are those of vertebras, which in some cases give only sharp pain syndromes, however they all result in lowering the height, deepening the pectoral kyphosis, reducing the capacity of lungs and disturbing the venous outflow from lower body parts. As for fractures other than vertebral ones, they concern the thigh bone, pelvis, ribs, radial and tibial bones and humerus. Fractures of the upper extremity of the femur, that is the femoral neck fractures, pertrochanteric and intertrochanteric fractures are the most dangerous effects of osteoporosis, resulting in the risk of considerable disability and even death [4, 7]. The epidemiological research has proved that as many as $30-50 \%$ of women over 50 years old will experience osteoporotic fractures, and $20-45 \%$ of people affected by the thigh bone fracture will die as a result of complications connected with it $[7,8]$. The occurrence of the fracture greatly increases the risk of further fractures. According to KohmannGolc et al. [9], the vertebra fracture constitutes a risk factor for not only another fracture within the spine, but also another osteoporotic fracture. For example, af- 
ter breaking the body of vertebra, the risk of another similar fracture grows 11 times, whereas the risk of the fracture of the upper extremity of the femur grows 2-3 times. The fracture of the upper extremity of the femur increases the risk of a fracture of the opposite end six times [10].

Referring to the problem of the postmenopausal osteoporosis it must be pointed out that the process of the decrease in the bone mass among women starts at the age of 30 and is about $1 \%$ in the cancellous bone and $0.3-0.5 \%$ in the cortical bone per year and then considerably rises to $4-8 \%$ of the mass loss in the trabecular layer and $2-3 \%$ in the cortical bone yearly after the menopause [11].

Grywalska et al. [3] claim that the increase in the bone mass loss already begins 2-3 years before the last menstruation and is estimated at $1.2-2 \%$ yearly. The sudden mass loss can persist throughout 8-10 years of the postmenopausal period, even up to 15 years, whereas later on this process gradually slows down [11]. Mass loss of women's trabecular bone can come up to even 55-60\% during several decades of predomination of the resorption processes over the boneforming processes, whereas in the cortical bone the value can come up to $35-40 \%$. As a result of permanent reduction in bone density, the so-called threshold of fractures is crossed, when even a very little impact on the skeleton results in a fracture.

\section{The diagnosis of osteoporosis and the fracture risk assessment}

The basic element in the diagnosis of osteoporosis of postmenopausal women is assessment of the BMD (bone mineral density), absolute 10-year risk of fractures and experienced osteoporotic fractures [4, 14]. The World Health Organization (WHO) recommends diagnosis of osteoporosis based on the BMD assessment of the upper extremity of the femur or vertebras of women in the postmenopausal age and of men over 50 years of age by means of dual energy X-ray absorptiometry (DEXA) using the $T$ indicator expressed as the number of standard deviations, where top bone mass is the point of reference. Therefore, the $T$-score gives us standard deviation of the BMD measured value from top bone mass of young adults of the same sex (NAMS) and is regarded as particularly useful in expressing BMD of women of postmenopausal age $[4,5$, 12-14]. Criteria of diagnosing osteoporosis of postmenopausal women and of men according to WHO: correct value $>-1 \mathrm{SD}$, osteopenia from -1 to $-2.5 \mathrm{SD}$, osteoporosis $<-2.5 \mathrm{SD}$, advanced osteoporosis $<-2.5 \mathrm{SD}$ and osteoporotic fracture [4, 14].

In cases of children and young people we use the Z-score which refers the measured mineral density of a patient's skeleton to the average value in the con- trol group, which is made up of people of the same sex and age, in the same ethnic group. Z-score is preferred as the BMD determining factor in the population of women in the premenopausal age $[4,14]$.

With reference to previous contents it must be accepted that in spite of the fact that the lowered value of the bone mineral density means the increase in the risk of a fracture, it is necessary to remember that the correct level of BMD does not exclude the risk of a fracture completely. Therefore, at present it is emphasised that an increased risk of a fracture is the essence of osteoporosis [5, 15]. Diagnosing osteoporosis is based on densitometric indicators but with clinical risk factors for fractures added they increase sensitivity without reducing the specificity. Connecting densitometric values with chosen clinical risk factors for fractures is the basis of the FRAX algorithm (WHO Fracture Risk Assessment Tool) drawn up in 2008 under the direction of Professor J. Kanis. In 2012, a group of experts of the European Society for Clinical and Economic Aspects of Osteoporosis and Osteoarthritis (ESCEO) and International Osteoporosis Foundation (IOF) under J. Kanis' direction updated European recommendations of 2008 concerning diagnostic and therapeutic procedures in postmenopausal osteoporosis of women, simultaneously calling for creating local guidelines in particular countries [16]. Assessing an absolute risk of fractures, taking the life span into account, allowed for developing FRAX algorithms for various countries, including Poland. By means of the fracture risk calculator FRAX, it is possible to calculate 10-year risk of major fractures, that is of $B K K U$, the vertebra, the radial bone and the humerus of women in the postmenopausal age and of men over 50 years of age and individually BKKU hip fracture. The FRAX TM algorithm links clinical risk factors for fractures (age from 40 up to 90 years, sex, presence of the osteoporotic fracture, BKKU fracture in parents, current smoking, excessive alcohol use over $30 \mathrm{~g} /$ day, taking glucocorticosteroids at present or in the past for 3 or more months, rheumatoid arthritis, other secondary osteoporoses with the BMI body mass index or also from BMD of the femur neck $[4,14]$. The thresholds accepted in Poland for the next 10 years are as follows:

- over 10\% - great risk (pharmacological treatment recommended),

- 5-10\% - average risk (more in-depth diagnostic procedures required),

- under $5 \%$ - little risk (preventive action recommended) $[4,16,17]$.

It must be pointed out that apart from the FRAX calculator, there are also other algorithms of a fracture risk, such as British QFracture, German domestic algorithm drawn up by Dachverband Osteologie or the Garvan's tool used in Australia [16].

Recommendations of the diagnostic procedure with reference to osteoporosis were based on a 2-stage proce- 
dure. The first stage conducted by general practitioners aims at selection and division of patients into a group qualifying to the preventive procedure and a group requiring further diagnostic tests for osteoporosis with particular reference to the patients after fractures of the spine and of the upper extremity of the femur. The clinical assessment should be made on the basis of subjective examination (determining factors for little bone mass, risks of fractures and risks of falls) and of medical examination (identifying the threat of the bone mass loss and the risk of vertebral fractures and falls). Subjective examination consists of the following:

- the measurement of BMI - the low BMI poses a threat of bone mass loss,

- the measurement of the height - loss of more than $3 \mathrm{~cm}$ is a recommendation for the X-ray of the pectoral and lumbar spine, on account of the suspicion of vertebral fractures,

- shortening of the rib-hip segment to less than 3-4 cm constitutes the suspicion of vertebral fractures,

- the kyphosis measurement of more than $5 \mathrm{~cm}$ indicates a vertebral fracture,

- carrying out a "get up and go" test - studying the threat of a fall.

The fracture risk assessment must be made by means of the qualitative method on the basis of identification of fracture risk factors both included and not included in the FRAX algorithm (early menopause, tendency to falls, hypogonadism, malabsorption syndrome, increased bone metabolism, anorexia nervosa, immobility, transplants of organs, deficiency of oestrogens, chronic renal failure, primary hyperparathyroidism, deficiency of vitamin $D$, the supply of calcium below $500 \mathrm{mg} / \mathrm{d}$, ankylosing spondylitis, diabetes, hyperthyroidism, anticonvulsant treatment) and of quantitative method. The quantitative method of the risk assessment of major fractures in postmenopausal women and in elderly men should be made using the Polish version of the FRAX calculator with BMI. 5\% risk of fractures both for the version with $\mathrm{BMI}$ as well as with BMD constitutes the decision-making threshold for further diagnostics of major fractures. The value of $10 \%$ or more for any fracture and over $3 \%$ for the upper extremity of the femur is regarded as a high risk and constitutes the threshold of pharmacological intervention $[4,17]$. We must remember about the need for the radiological assessment of the pectoral and lumbar spine in the case of significant kyphosis, shortening of the rib-hip segment or reducing the height by over $3 \mathrm{~cm}$ when vertebral fractures are suspected [4].

The second stage of osteoporosis diagnostic procedure conducted by the doctor of the Osteoporosis Clinic consists of:

- the verification of the fracture threat because of primary and secondary causes as well as determining possible elimination or alteration of fracture risk factors,
- diagnosing the fracture risk (the analysis of BMD, X-ray, morphometry, the rate of bone metabolism),

- selecting appropriate preventive, treatment and rehabilitation procedures,

- verification of the procedure effectiveness.

During the verification of the fracture threat it is necessary to make an analysis of clinical risk factors, to establish diagnosis diversifying primary and secondary osteoporosis as well as excluding other osteoporosis causes of little bone mass or fractures.

At this stage it is reasonable to conduct a comprehensive 10-year fracture risk assessment, based on the verification of the sex and age, test results, such as tomodensitometry, bone metabolism, asymptomatic fractures of vertebral body as well as bone-related and other than bone related fracture risk factors, above all the therapy with drugs from a group of corticoids lasting longer than 3 months. The assessment of the fracture risk should be made after doing tomodensitometry of the upper extremity of the femur with the DEXA method, using the tabular algorithm, determining the 10-year risk of osteoporotic fractures in Poland according to FRAX TM depending on the age and the result of the tomodensitometry (without other risk factors: BMI $24 \mathrm{~kg} / \mathrm{m}^{2}$ ). In this algorithm, a BMD value of the femur neck has been used because there are no standards developed for the assessment of the appendicular skeleton (the algorithm cannot be used for monitoring patients undergoing pharmacological therapy). The table allows to identify the little risk of a fracture $-<5 \%$, average $-5-10 \%$ and large $->10 \%$. However, we must remember about situations which oblige us to change the group of fracture risk. The $T$-score under $-2.5 \mathrm{SD}$ is regarded as equivalent to at least an average fracture risk and constitutes a recommendation for further diagnostic tests, regardless of age. Also a long-term therapy with glucocorticosteroids as well as the accelerated bone metabolism in postmenopausal women increase the fracture risk by one degree. Multiple fractures increase the risk of further fractures to a larger degree than single ones, especially the fracture of the upper extremity of the femur and vertebral ones. Fractures of this type, including so-called silent fractures, i.e. accidentally detected, confirmed in the X-ray or in morphometry are equivalent to a high risk of fractures [4].

We also make the fracture risk assessment by means of a computer version of FRAX TM algorithm for Poland.

Discussing issues of recognizing and diagnosing osteoporosis we must show current criteria for drug treatment. Pharmacological therapy is recommended to patients with a large 10-year fracture risk of $->10 \%$ determined on the basis of comprehensive analysis of risk factors and after the fracture of the upper extremity of the femur or the vertebra. When doing tomodensitometry is impossible, clinical risk factors must be taken 
into account when qualifying for treatment, the presence of vertebral deformation found in the X-ray, the height reduction by over $3 \mathrm{~cm}$ and in the case of postmenopausal women - accelerated bone metabolism, confirmed after checking the concentration of markers in the blood serum $[4,17]$.

\section{Prevention of falls}

In the literature on the subject [18], a fall is defined as "a sudden and unintentional... change of the position of the body from the existing level to a lower one". Since falls constitute a direct reason for low-energy fractures, including about $25 \%$ of back injuries and $90-100 \%$ of fractures concerning extravertebral sites, therefore preventing them constitutes an essential stage in the treatment of osteoporosis. The literature contains information, according to which $40 \%$ of individuals generally regarded as healthy aged over 65 experience falls on average once a year, whereas upon 80 years of age, this problem regards even $50 \%$ of individuals [21]. Statistical data demonstrate that women fall three times more often than men.

$5 \%$ of falls result in osteoporotic fractures, and about $60 \%$ of falls occur at home. Therefore, every elderly person, irrespective of whether he/she has osteoporosis or not, should be educated on how to avoid falls [21, 22]. It turned out that falls had not only medical consequences in the form of fractures, but also due to the injury, result in the reduced motor efficiency as well as in the large portion of cases lead to the anxiety about another collapse, called "the post-fall syndrome". "The post-fall syndrome" is characterized by confusion, depression, and in the end, becoming dependent on others [23, 24].

Causes of falls can be generally divided into external and internal ones.

External factors, also called environmental ones, are [2, 4, 24]:

- home factors - inappropriate lighting, rickety rugs, uneven and slippery floors, high thresholds, obstacles in the walk area (power cords, objects left about), wrong footwear, stairs, lack of railings and handles in the bathroom, pets moving around the house,

- outside the house - bumpy pavements, slippery, icy, wet surfaces.

Internal factors, also called medical ones, are [2, 6, 24]

- walking disturbances, problems in keeping the balance, reducing the activity, limitation of the scope of movements in joints, weakening of muscle power, limiting the vision, memory disorders,

- heart diseases and neurological diseases with faints occurring,

- taking sedative, cardiological and psychoactive medicines, multi-drug therapy.

All individuals at an increased risk of falling should be provided with a multifactorial fall prevention pro- gramme, which should comprise the following elements [23]:

\section{Selecting people in danger of a fall.}

According to the recommendations of the National Institute for Clinical Excellence in Great Britain, we should ask every elderly person if they experienced a fall in the last year and, if the fall is reported, the patient should undergo the mobility, walking ability and the balance test, e.g. "get up and go" test. The assessment of muscle strength and physical fitness is also important, as well as the analysis of the static balance, e.g. doing the test of keeping the static balance in the "tandem" position, or by using the computer balance platform. In order to make an appropriate assessment of the degree of elderly people's fitness, it is also possible to do tests of the self-service fitness in everyday life activities (Lawton's Scale - the Scale of the Assessment of Complex Activities of Everyday Life), of mental state in the context of cognitive functions and memory disorders (MMSE test) as well as depression (GDS test - Geriatric Depression Scale) [19]. We must also mention the algorithm of Nguyen and associates, also referred to as Garvan's model or Dubbo monogram. This tool was created on the basis of the Australian Dubbo Osteoporosis Epidemiology Study (DOES) and it enables numerical fracture risk assessment, considering clinical factors of the fracture as well as the falls [25].

2. Analysis of falls in the context of many risk factors.

One should perform a multifactorial risk analysis of falls for individuals, whose results of fitness tests are incorrect, or after a low-energy fracture, on a case-bycase basis for every patient, using applicable criteria. Such analysis should concern $[4,23,26]$ :

- characteristics of falls,

- selected possible risk factors for falling ill and the socalled home factors of the fall,

- general condition of the patient, especially eyes, the cardiovascular system, central nervous system, state of the memory,

- level of the efficiency, balance, walk and strength of muscles,

- disorders concerning urinary incontinence,

- evaluation and a possible change of applied pharmacological therapy.

3. Implementation of a multifactorial fall prevention programme.

For the implementation of assumptions of the multifactorial low-energy fall prevention programme, one should take into consideration the most essential areas of preventive action, that is [4, 23, 26]:

- training to increase strength and balance,

- elimination of outside, especially home, risk factors for falls,

- improvement of the health condition of individuals at risk of falls, 
- verification of the drug treatment in order to lower the risk of falls.

The World Health Organization (WHO), noticing a connection between the majority of medical risk factors and the efficiency of the organism, recognised the correct physical activity to be the priority preventive factor in the context of low-energy falls. The kind and character of exercises are established adequately to the age, general health state, condition and experienced fractures. Weight training is recommended under the weight of the own body and also aerobic physical effort. Recommending exercises of safe performance of everyday activities seems important, based on appropriate models, aimed to learn how to avoid dangerous bending and rotation of the spine [24].

Although in fall prevention exercises under the direction of the physiotherapist or kinesigerontoprophylaxis trainer are crucial, it is also one's own activity that is not meaningless. Especially swimming is recommended, cycling in the flat countryside, brisk walking, Nordic walking, or dancing $[2,24]$. One should note that in order to reduce consequences of the fall, it may prove essential to learn how to "fall down" and how to "get up after the fall". It turned out that falls aside, that is regions of the hip belong to falls with the greatest fall risk, whereas falls onto buttocks are the least dangerous $[27,28]$.

Since it results from the research that the majority of falls happen at home, actions aimed at eliminating so-called 'home risk factors' are essential. One should see to removing objects lying on the floor, power cords, secure edges coming off carpets, remove slippery rugs and wear anti-skidding stable heel shoes. The bathroom should be equipped with appropriate railings and handles and anti-skidding rugs, which also to a large extent contributes to fall prevention. The right, not-blinding system of lighting is particularly important for individuals at risk, especially in such places as stairs, thresholds, or roughness of the floor. If necessary, if someone has a regular tendency to falls, one should use walking frames, walking sticks, or pads on hips.

The research shows that applying pads on hips can reduce the risk of the fracture of the upper extremity of the femur even by $50 \%$. When being away from home one should remember always to have "free hands" in order to absorb the possible fall. Therefore, it is necessary to avoid carrying bags in the hand, and exchange these for a backpack or a shoulder bag [24, 26, 28].

As part of the multifactorial fall prevention programme, the doctor should verify pharmacological treatment, sometimes by attempting to withdraw some medicines, especially psychoactive drugs. It turned out that eliminating them from therapy may reduce the risk of falls even by $66 \%$. Patients affected with comorbidities, above all concerning the central nervous system, the cardiovascular system, mental state disorders and organs of vision and hearing should also be provided with the specialist care, aimed at reducing the influence of these diseases on everyday life to prevent falls [26].

\section{Disclosure}

Authors report no conflicts of interest.

\section{References}

1. Roczniak W, Babuśka-Roczniak M, Roczniak A. Diagnostyka i farmakoterapia osteoporozy. Lekarz 2010; 12: 14-22.

2. Kowalczyk-Nowakowska J, Dmoch-Gajzlerska E. Zagrożenie osteoporozą w wieku okołomenopauzalnym. Położ Nauka Prakt 2009; 2: 12-17.

3. Grywalska E, Grafka A, Putowski L. Komórki macierzyste w leczeniu złamań towarzyszących osteoporozie - medyczne science fiction czy metoda terapii w przyszłości? Prz Menopauzalny 2011; 15: 378-382.

4. Lorenc R, Głuszko P, Karczmarewicz E. Zalecenia postępowania diagnostycznego i leczniczego w osteoporozie. Aktualizacja 2013. Med Prakt 2013; 1: 1-44.

5. Sobczuk A, Sobczuk K, Pertyński T. Nowe aspekty leczenia osteoporozy pomenopauzalnej. Prz Menopauzalny 2011; 6: 480-486.

6. Lorenc R, Głuszko P, Karczmarewicz E. Zalecenia postępowania diagnostycznego i leczniczego w osteoporozie. Obniżenie częstości złamań poprzez efektywną profilaktykę i leczenie. Terapia 2007; 9: 11-33.

7. Marcinkowska M, Horst-Sikorska W, Wawrzyniak A, et al. Czynniki rokownicze po złamaniu bliższego końca kości udowej u kobiet z osteoporozą pomenopauzalną. Prz Menopauzalny 2012; 2: 124-128.

8. Gerkowicz A, Pietrzak A, Nogalski A. Łuszczyca a osteoporoza. Łuszczyca a menopauza. Część 3. Prz Menopauzalny 2013; 2: 159-162.

9. Kohmann-Golc A, Przedlacki J, Mickiewicz-Łączyńska A, et al. Rola morfometrii densytometrycznej (verbal fracture assessment) w diagnostyce złamań kręgosłupa. Reumatologia 2012; 50: 35-39.

10. Marczyński W, Górecki A, Czerwiński E. Zasady profilaktyki, rozpoznawania i leczenia osteoporotycznych złamań kości. Ortop Traumatol Rehab 2007; 9: 548-554.

11. Tałałaj M. Budowa kości, jej wzrost i zanikanie. W: Osteoporoza. Marcinowska-Suchowierska E (ed.). Wydawnictwo Lekarskie PZWL, Warszawa 2004; 32-49.

12. Tkaczuk-Włach J, Sobstyl M, Jakiel G. Osteoporoza - obraz kliniczny, czynniki ryzyka i diagnostyka. Prz Menopauzalny 2010; 2: 113-117.

13. Pawlak-Buś K, Leszczyński P. Farmakoterapia parenteralna i doustna w zapobieganiu złamaniom w przebiegu osteoporozy pomenopauzalnej. Prz Menopauzalny 2013; 3: 271-277.

14. Kanis J, McCloskey EV, Johansson $\mathrm{H}$, et al. European guidance for the diagnosis and management of osteoporosis in postmenopausal women. Osteopor Int 2012; doi: 10.1007/s00 198-012-2074-y.

15. Czerwiński E, Badurski J, Lorenc R. Wytyczne w sprawie diagnostyki osteoporozy i oceny ryzyka złamania w Polsce III Środkowoeuropejskiego Kongresu Osteoporozy i Osteoartrozy, XV Zjazdu Polskiego Towarzystwa Osteoartrologii i Polskiej Fundacji Osteoporozy. Zeszyt Edukacyjny Osteoporoza i Choroby Metaboliczne Kości. Med Dypl 2010; 1: 2-6.

16. Głuszko P, Karczmarewicz E, Lorenc R. Osteoporoza - postępy 2012. Med Prakt 2013; 6 .

17. Buczkowski K, Chlabicz S, Horst-Sikorska W, et al. Osteoporoza. Postępowanie profilaktyczne, diagnostyczne i lecznicze. Wytyczne dla lekarzy podstawowej opieki zdrowotnej. Forum Med Rodz 2012; 6: 153-160.

18. Czerwiński E, Borowy P. Wytyczne dotyczące profilaktyki osteoporozy ze szczególnym uwzględnieniem zapobiegania upadkom. Terapia 2006; 3: 30-36.

19. Skalska A, Gałaś A. Upadki jako czynnik ryzyka pogorszenia stanu funkcjonalnego w starszym wieku. Gerontol Pol 2011; 19: 150-160.

20. Kotwica Z, Saracen A. Wczesne i odległe wyniki leczenia pojedynczych złamań osteoporotycznych za pomocą wertebroplastyki. Neurol Neuroch Pol 2011; 45: 431-435.

21. Czerwiński E. Przełom w diagnostyce osteoporozy i jej współczesne leczenie. In: Kruczyński J (ed.). Postępy w zakresie epidemiologii, stanu profilaktyki, diagnostyki i leczenia chorób układu kostno-stawowego 
w Polsce i na świecie w okresie dekady 2000-2010. Fundacja Rozwoju Ortopedii i Rehabilitacji, Warszawa 2010; 163-166.

22. Głuszko P, Lorenc R. Zalecenia postępowania diagnostycznego i terapeutycznego. Osteoporoza pierwotna i wtórna. Wskazówki postępowania dla reumatologów. Reumatologia 2012; 50: 370-377.

23. Marcinowska-Suchowierska E, Czerwiński E, Badurki J. Osteoporoza diagnostyka i terapia u osób starszych. Post Nauk Med 2011; 5: 410-423.

24. Milert A. Postaw kości na nogi. Mag Pielęg Położ 2011; 6: 24-25.

25. Dytfeld J, Marcinkowska M, Ignaszak-Szczepaniak M. Porównanie przydatności kalkulatora FRAX oraz Nguyena do oceny ryzyka złamania niskoenergetycznego oraz kwalifikacji do rozpoczęcia terapii u polskich kobiet z osteoporozą pomenopauzalną. Prz Menopauzalny 2011; 15: 473-479.
26. Czerwiński E, Borowy P, Jasiek B. Współczesne zasady zapobiegania upadkom z wykorzystaniem rehabilitacji. Ortop Traumatol Rehab 2006; 4: 380-387.

27. Pietraszkiewicz F. Ocena sprawności. In: Osteoporoza. Praktyczne zasady opieki lekarskiej nad chorym z osteoporozą. Pluskiewicz W (ed.). Med Trib Pol, Warszawa 2010; 23-30.

28. Pluskiewicz W. Zapobieganie upadkom. In: Osteoporoza. Praktyczne zasady opieki lekarskiej nad chorym z osteoporozą. Pluskiewicz W (ed.). Med Trib Pol, Warszawa 2010; 86-87. 